\title{
Identifikasi Penyakit pada Sel Darah Menggunakan Logika Fuzzy Mamdani
}

Hardianto $^{\mathrm{a}}$, Nurhasanah ${ }^{\mathrm{a}^{*}}$

\author{
aProgram Studi Fisika, Jurusan Fisika, FMIPA Universitas Tanjungpura \\ Jalan Prof. Dr. Hadari Nawawi, Pontianak, Indonesia \\ *Email : nurhasanah@physics.untan.ac.id
}

\begin{abstract}
Abstrak
Identifikasi penyakit darah melalui citra sel darah manusia telah dilakukan menggunakan ekstraksi ciri Gray Level Co-occurrence Matrix dan metode logika fuzzy mamdani. Citra yang digunakan terdiri dari 10 citra leukemia dan 10 citra anemia. Tahap preprocessing diawali dengan memotong citra menjadi $430 \times 307$ piksel, kemudian mengubah citra berwarna menjadi citra beraras keabuan (grayscale), menghitung histogram citra, dan melakukan proses segmentasi. Setelah preprocessing, ciri statistic citra diekstraksi menggunakan Gray Level Co-occurence Matrix 4 arah $\left(0^{\circ}, 45^{\circ}, 9^{\circ}\right.$, dan $\left.135^{\circ}\right)$ pada jarak d $=1$. Fitur yang digunakan pada proses ini adalah kontras, korelasi, energi, dan homogenitas. Data dari ekstraksi ciri diidentifikasi menggunakan logika fuzzy dengan metode inferensi mamdani. Sistem identifikasi ini ditampilkan dalam bentuk Grafichal User Interface. Identifikasi menggunakan metode tersebut menghasilkan akurasi data pelatihan dan data uji, berturut-turut sebesar 93,75\% dan 100\%. Dari hasil yang diperoleh dapat disimpulkan bahwa metode yang digunakan pada penelitian ini dapat diaplikasikan untuk mengidentifikasi penyakit sel darah dengan akurasi yang tinggi.
\end{abstract}

Kata Kunci: Citra Sel Darah, GLCM, Logika Fuzzy Mamdani

\section{Latar Belakang}

Darah merupakan bagian terpenting dari tubuh yang berfungsi dalam transportasi zat, pengatur keseimbangan, dan lain sebagainya. Darah yang beredar dalam tubuh dapat digunakan untuk mengidentifikasi kesehatan seseorang melalui serangkaian tes darah [1]. Kondisi darah yang tidak normal akan menyebabkan beberapa bagian dari darah tidak berfungsi sebagaimana mestinya. Kelainan darah bisa menyebabkan berbagai jenis penyakit, seperti leukemia, kanker, diabetes, dan lain-lain.

Perhitungan secara manual untuk mendeteksi kelainan darah dapat dilakukan menggunakan mikroskop, hemocytometer, dan hematology analyzer. Identifikasi penyakit menggunakan alat-alat tersebut masih memerlukan analisis lebih lanjut, sehingga memerlukan waktu yang cukup lama. Seiring dengan berkembangnya teknologi, pemeriksaan dapat dilakukan menggunakan pengenalan pola citra. Untuk keperluan tersebut, citra darah dapat diperoleh dengan menggunakan perangkat scanning electron microscope (SEM). Citra yang dihasilkan kemudian digunakan untuk mengidentifikasi penyakit melalui aplikasi pengolahan citra digital.

Secara umum, pendeteksian penyakit melalui analisis citra sel darah memerlukan teknik pengolahan citra dan ekstraksi ciri. Identifikasi penyakit leukemia akut pada citra darah mikroskopis dengan metode classifier $k$ Nearest Neighbor (kNN) dengan kinerja mencapai 94\% [1]. Selain itu, pendeteksian anemia pada sel darah merah telah dilakukan menggunakan metode segmentasi deteksi tepi canny dengan accuracy sebesar 85,71\% [2].

Informasi suatu objek diketahui melalui ciri bentuk, ciri tekstur, dan ciri warna. Gray Level Cooccurance Matrix (GLCM) merupakan salah satu metode ekstraksi ciri tekstur. Penggunaan GLCM telah digunakan, diantaranya, pada klasifikasi massa citra mammogram berdasarkan GLCM 4 arah dengan akurasi sebesar 81,1\% [3]. Penerapan metode GLCM yang dilengkapi dengan metode tranformasi wavelet telah digunakan untuk menganalisis tekstur citra mikroskopis kanker paru dengan akurasi hingga $80 \%$ [4].

Metode fuzzy mamdani merupakan salah satu metode penalaran (inference) yang digunakan untuk masalah-masalah yang mengandung ketidakpastian dan ketidaktepatan. Konsep logika fuzzy mamdani yang sederhana dan mudah dimengerti mampu memberikan toleransi terhadap data-data yang tidak tepat. Penelitian terkait, seperti penggunaan pohon keputusan fuzzy berbasis gini index untuk mengidentifikasi sel darah merah bertumpuk, menunjukan hasil akurasi 96,14\% [5]. Selain itu, diagnosa penyakit jantung dan paru dengan fuzzy logic dan centainty factor telah dilakukan dengan tingkat kemiripan sebesar 94.61\% [6].

Berdasarkan uraian yang telah dijabarkan, pada penelitian ini, akan dilakukan identifikasi penyakit pada sel darah menggunakan logika fuzzy mamdani. Ciri citra input diperoleh melalui metode GLCM. Dalam implementasinya, digunakan GLCM 4 arah, yaitu $0^{\circ}, 45^{\circ}, 90^{\circ}$ dan $135^{\circ}$ dengan jarak spasial1. Pada penelitian ini, 
dilakukan pula perancangan Graphic User Interface (GUI) sebagai antarmuka pengguna untuk mempermudah proses analisis citra darah.

\section{Metodologi}

\section{Data Penelitian}

Data yang digunakan merupakan citra sel darah dari dataset ATLAS OF HEMATOLOGY. Citra yang digunakan terdiri dari 10 citra leukemia dan 10 citra anemia. Data citra tersebut dibagi menjadi 16 data citra latih dan 4 data citra uji.

\section{Preprocessing}

Pengolahan dan perbaikan citra (preprocessing) diperlukan untuk meningkatkan kualitas citra supaya mudah diolah untuk prosesproses selanjutnya [7]. Proses pengolahan citra terdiri dari:

\section{Pemotongan Citra}

Pemotongan citra atau cropping dilakukan untuk mengambil bagian citra sebagai input yang akan diamati dengan ukuran yang sama [8]. Pada tahap ini citra asli di-cropping dengan ukuran $430 \times 307$ piksel.

\section{Grayscalling}

Grayscalling merupakan sebuah proses mengubah citra berwarna (RGB) menjadi citra beraras keabuan (grayscale). Persamaan yang digunakan untuk mendapatkan citra grayscale [9]:

$$
\text { gray }=0.299 \mathrm{R}+0.587 \mathrm{G}+0.114 \mathrm{~B}
$$

dengan $\mathrm{R}$ adalah nilai bagian Red, $\mathrm{G}$ nilai bagian Green dan B adalah nilai bagian Blue.

\section{Perhitungan Histogram}

Histogram citra ditampilkan untuk memberikan informasi nilai sebaran keabuan pada citra yang kemudian digunakan untuk mengetahui rentang piksel pada citra grayscale.

4. Segmentasi

Segmentasi citra bertujuan untuk memisahkan latar belakang dengan objek. Segmentasi citra yang digunakan adalah metode pengambangan atau thresholding. Citra dengan histogram di atas nilai ambang akan bernilai 1 dan di bawah nilai ambang bernilai 0. Citra yang dihasilkan adalah citra biner. Nilai ambang (T) didapat dari persamaan berikut [10]:

$$
T=\frac{f_{\max }-f_{\min }}{2}
$$

$f_{\text {max }}$ adalah nilai intensitas maksimum dan $f_{\min }$ adalah nilai intensitas minimum.

\section{Ekstraksi Ciri Citra}

Ekstrasi ciri menggunakan Gray Level Cooccurrence Matrix (GLCM). GLCM merupakan salah satu metode yang digunakan untuk analisis tekstur. Analisis tekstur ditentukan dari matriks ko-okurensi suatu citra dengan melihat pasangan piksel-piksel yang memiliki intensitas tertentu. Ko-okurensi merupakan jumlah kejadian satu level nilai piksel bertetangga dengan satu level nilai piksel lain dalam jarak (d) dan orientasi sudut $(\theta)$ tertentu. Orientasi sudut dinyatakan dengan derajat yaitu 0, 45, 90 dan 135 [11] seperti Gambar 1.

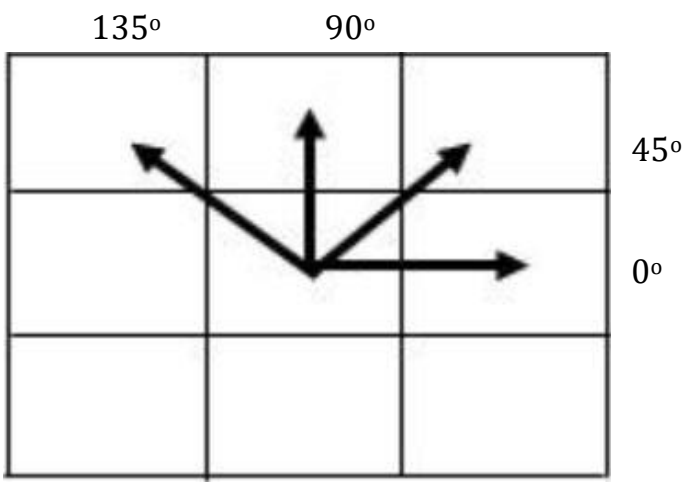

Gambar 1 Orientasi sudut 4 arah

Setelah matriks ko-okurensi ditentukan, setiap elemen dijumlahkan dengan transpose dan dibagi dengan jumlah total semua elemen. Langkah selanjutnya adalah menghitung ciri statistik GLCM. Ciri statistik tersebut adalah:

1. Energi

Energi menyatakan ukuran konsentrasi pasangan dengan intensitas keabuan tertentu pada matriks. Energi mencapai nilai maksimum jika bernilai satu. Nilai energi didapat dengan persamaan sebagai berikut [12]:

$E=\sum_{i} \sum_{j} p(i, j)^{2}$

dengan $E$ adalah nilai dari energi dan $p(i, j)$ merupakan probabilitas dibaris $i$ dan dikolom $j$.

2. Homogenitas

Homogenitas digunakan untuk mengukur kehomogenan variasi intensitas citra. Nilai homogenitas akan relatif membesar apabila variasi intensitas dalam citra mengecil. Nilai homogenitas didapat dengan persamaan sebagai berikut [12]:

$H=\sum_{i} \sum_{j} \frac{p(i, j)}{1+|i-j|}$

dengan $H$ adalah nilai dari homogenitas citra sedangkan $i$ dan $j$ adalah baris dan kolom.

3. Korelasi

Korelasi digunakan untuk mengukur ketergantungan linear derajat keabuan di sekitar piksel. Nilai-nilai korelasi tinggi (mendekati satu) menandakan sebuah hubungan yang linear antara tingkat abuan dari pasangan piksel. Nilai 
korelasi dinyatakan dengan persamaan sebagai berikut [12]:

Corr $=\sum_{i} \sum_{j} \frac{\left(i-\mu_{x}\right)\left(j-\mu_{y}\right)}{\sigma_{x} \sigma_{y}} P(i, j)$

Dengan $\mu_{x}$ adalah nilai rata-rata elemen baris pada matriks $p(i, j)$ dan $\mu_{y}$ adalah nilai rata-rata elemen kolom pada matriks $p(i, j)$. Sedangkan $\sigma_{\mathrm{x}}$ dan $\sigma_{\mathrm{y}}$ merupakan standar deviasi dari elemen baris dan kolom pada matrik $p(i, j)$.

4. Kontras

Kontras merupakan perbedaan intensitas antara nilai tertinggi (terang) dan nilai terendah (gelap) dari seperangkat piksel yang saling berdekatan. Nilai kontras dinyatakan dengan persamaan sebagai berikut [12]:

$$
\text { Con }=\sum_{i} \sum_{j}(i-j)^{2} p(i, j)
$$

Proses perhitungan ciri statistik dapat dilihat pada diagram alir berikut.
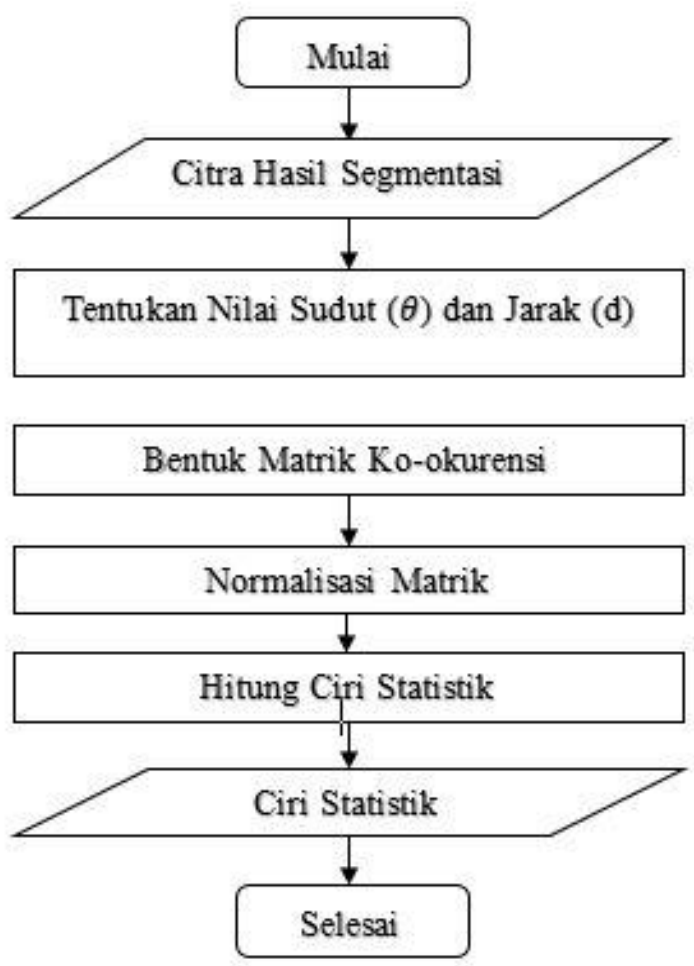

Gambar 2 Diagram alir ekstraksi ciri GLCM

\section{Perancangan Logika Fuzzy}

Logika Fuzzy adalah logika yang memiliki nilai kekaburan yang elemennya berada pada selang 0 sampai 1 . Logika fuzzy mamdani merupakan metode dimana nilai minimum digunakan sebagai fungsi implikasi, sedangkan komposisi aturan digunakan nilai maksimum [13]. Proses logika fuzzy mamdani dilakukan seperti pada Gambar 3.

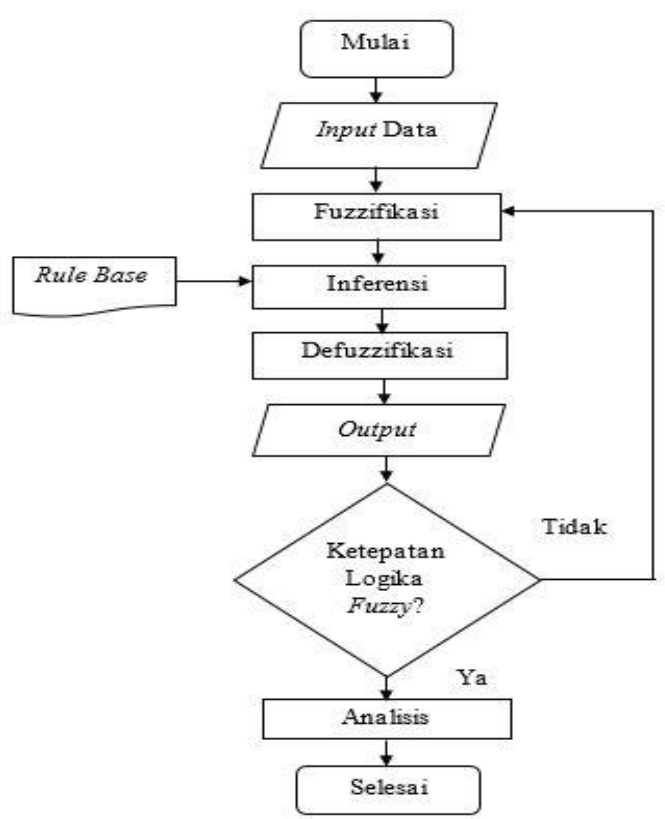

Gambar 3 Diagram logika fuzzy

Sistem fuzzy dibangun dari beberapa tahapan, seperti fuzzifikasi, pembentukan aturan fuzzy, inferensi fuzzy dan defuzzifikasi. Citra sel darah dibagi menjadi dua bagian, yaitu bagian pertama digunakan sebagai citra latih dan bagian kedua digunakan sebagai citra uji. Data input yang digunakan pada citra latih dan citra uji yaitu berupa kontras, korelasi, energi dan homogenitas. Representasi kurva yang digunakan adalah kurva segitiga. Berikut merupakan Gambar representasi dan persamaan pada kurva segitiga:

$\alpha(x)=\left\{\begin{array}{c}0 ; x \leq a \text { dan } x \geq c \\ \frac{x-a}{b-a} ; a \leq x \leq b \\ \frac{c-x}{c-b} ; b \leq x \leq c\end{array}\right.$

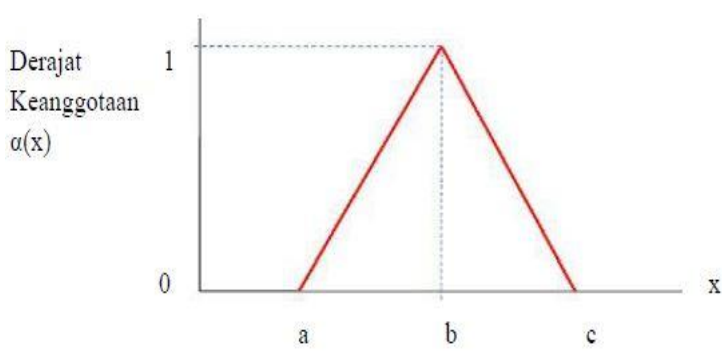

Gambar 4 Representasi kurva segitiga

Metode centroid digunakan untuk mendapatkan hasil defuzzifikasi. Pada metode ini solusi diperoleh dengan cara mengambil titik pusat $\left(z^{*}\right)$ daerah fuzzy. Persamaan centroid adalah sebagai berikut: 


$$
z^{*}=\frac{\int z \mu(z) d z}{\int \mu(z) d z}
$$

\section{Hasil dan Pembahasan Preprocessing}

Hasil pengolahan citra pada penyakit leukemia dan anemia ditunjukkan oleh Gambar 5.

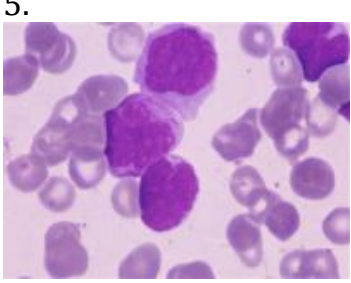

(a)

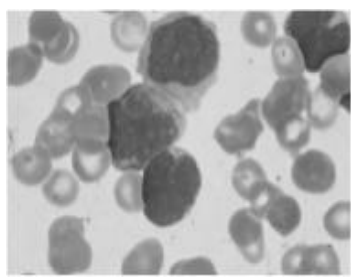

(c)

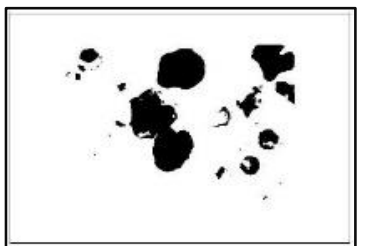

(e)

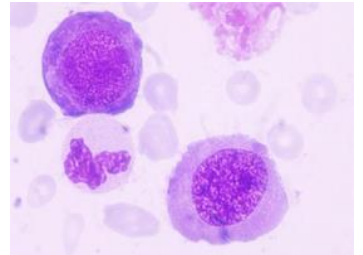

(b)

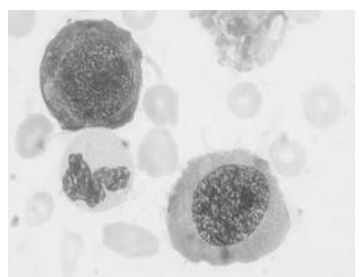

(d)

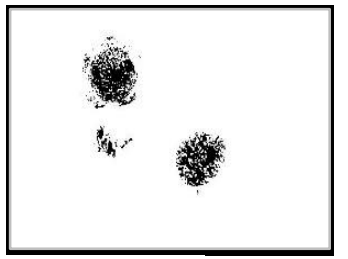

(f)
Gambar 5 Citra leukemia dan anemia, (a dan b) citra RGB, (c dan d) citra grayscale dan (e dan f) citra threshold

Pengolahan citra dimulai dengan meng-cropping citra RGB dengan ukuran $430 \times 307$ piksel (Gambar 5 a dan b). Dari citra tersebut dapat dilihat bahwa terdapat perbedaan bentuk dan tekstur. Citra leukemia cenderung lebih banyak dan bertumpuk sel darahnya, sedangkan citra anemia lebih menggumpal dan tidak bertumpuk. Gambar 5(c dan d) menunjukan citra yang telah dikonversi menjadi citra grayscale. Dari gambar tersebut, dapat dilihat citra bahwa hanya memiliki kombinasi warna hitam, abu-abu dan putih. Proses selanjutnya adalah penghapusan background yang bertujuan untuk menghilangkan objek yang tidak dperlukan. Gambar 5 (e dan f) menunjukan hasil citra berupa bercak hitam yang merupakan objek pada citra sel darah. Citra leukemia memiliki bercak hitam lebih banyak dari pada citra anemia.

Gambar 6 menunjukan hasil histogram dari citra leukemia dan anemia. Terlihat kedua citra tersebut termasuk citra terang karena distribusi nilai intensitas cenderung berada pada daerah sebelah kanan histogram dengan jumlah piksel yang berada pada nilai intensitas antara 200 250 lebih dari 2500 dan 5000 piksel.

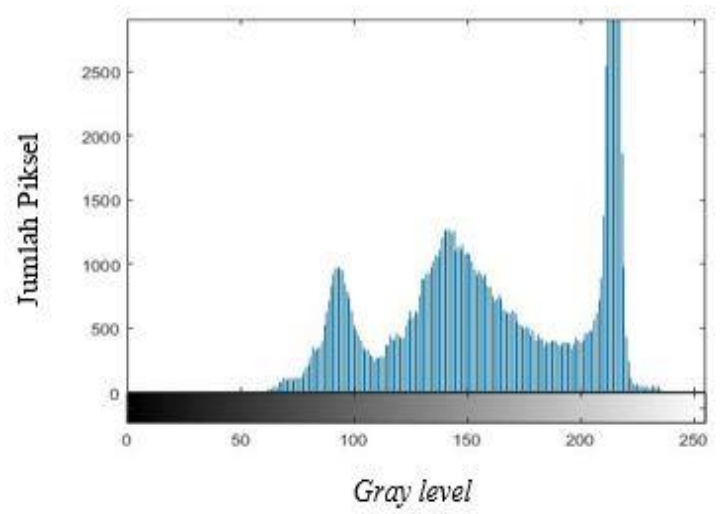

(a)

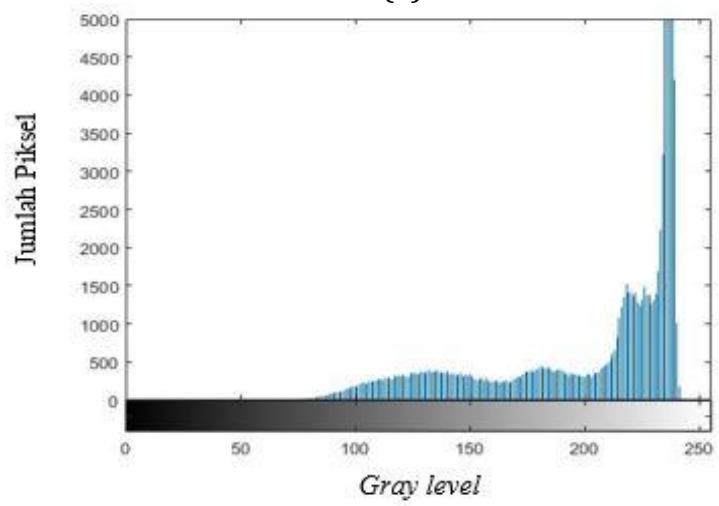

(b)

Gambar 6 Histogram (a)leukemia (b)anemia

\section{Ekstraksi Ciri}

Tabel 1 dan tabel 2 merupakan nilai minimum dan nilai maksimum ciri statistik dari data pelatihan dan data uji. Berdasarkan nilai perhitungan ciri statistik tersebut dapat diperoleh nilai-nilai citra leukemia dan anemia. Nilai kontras menunjukkan perbedaan intensitas antara terang dan gelap. Citra anemia memiliki nilai kontras lebih tinggi dengan nilai 19.368 sampai 56.349 dibandingkan dengan citra leukemia dengan nilai 15.055 sampai 35.364. Ukuran hubungan antara 1 piksel dengan piksel tetangganya ditunjukkan dengan nilai korelasi. Sedangkan ukuran keseragaman dan konsentrasi pasangan pada citra ditunjukkan oleh nilai homogenitas dan energi. Pada Tabel 1 dan 2 dapat dilihat citra leukemia memiliki nilai korelasi, energi dan homogenitas lebih tinggi dari citra anemia. Hal ini menunjukkan citra leukemia memiliki bentuk lebih homogen (seragam) dari citra anemia. 
Tabel 1. Nilai minimum dan nilai maksimum data pelatihan

\begin{tabular}{ccccccccc}
\hline \multirow{2}{*}{ Citra } & \multicolumn{2}{c}{ Kontras } & \multicolumn{2}{c}{ Korelasi } & \multicolumn{2}{c}{ Energi } & \multicolumn{2}{c}{ Homogeitas } \\
\cline { 2 - 9 } & Min & Max & Min & Max & Min & Max & Min & Max \\
\hline Leukemia & 15.055 & 28.3998 & 0.9404 & 0.9858 & 0.067 & 0.1811 & 0.6227 & 0.8675 \\
Anemia & 19.3677 & 56.349 & 0.9158 & 0.9758 & 0.0525 & 0.1663 & 0.7198 & 0.8376 \\
\hline
\end{tabular}

Sumber: Data pribadi

Tabel 2. Nilai minimum dan nilai maksimum data uji

\begin{tabular}{ccccccccc}
\hline \multirow{2}{*}{ Citra } & \multicolumn{2}{c}{ Kontras } & \multicolumn{2}{c}{ Korelasi } & \multicolumn{2}{c}{ Energi } & \multicolumn{2}{c}{ Homogeitas } \\
\cline { 2 - 9 } & Min & Max & Min & Max & Min & Max & Min & Max \\
\hline Leukemia & 16.2946 & 35.3641 & 0.971 & 0.9245 & 0.1318 & 0.0651 & 0.7905 & 0.7434 \\
Anemia & 21.6195 & 35.0071 & 0.935 & 0.9648 & 0.0345 & 0.0851 & 0.6848 & 0.8262 \\
\hline
\end{tabular}

Sumber: Data pribadi

\section{Analisa Fuzzy Mamdani}

Hasil perhitungan ciri statistik yang telah didapatkan, kemudian, diidentifikasi menggunakan logika fuzzy mamdani. Himpunan universal pada input dan output terdiri atas 16 variabel input dan 2 variabel output. Input yang digunakan dalam penelitian ini sebanyak 16, dengan setiap input terdiri dari 9 fungsi keanggotaan. Karena data pelatihan yang digunakan sebanyak 16 data citra sel darah, maka aturan yang terbentuk akan sama, yaitu 16 aturan. Operator irisan (AND) digunakan sebagai penggabung untuk semua variabel input. Setelah diperoleh hasil identifikasi dari sistem fuzzy, selanjutnya dihitung nilai akurasi untuk data pelatihan dan data uji. Hasil identifikasi data pelatihan dapat dilihat pada tabel 3 .

Tabel 3 Hasil identifikasi data pelatihan

\begin{tabular}{cccc}
\hline Citra & Jumlah & Identifikasi Benar & Akurasi \\
\hline L & 8 & 7 & $87.50 \%$ \\
A & 8 & 8 & $100 \%$ \\
\hline
\end{tabular}

Persentase akurasi dari proses identifikasi untuk data pelatihan diperoleh dengan persamaan sebagai berikut;

akurasi $=\frac{\text { data benar }}{\text { data keseluruhan }} \times 100 \%(9)$

Data benar merupakan jumlah citra leukemia dan anemia yang teridentifikasi benar. Sedangkan data keseluruhan merupakan jumlah semua data yang digunakan dalam identifikasi. Dari Tabel 3 didapatkan nilai akurasi data pelatihan sebagai berikut:

$$
\text { akurasi }=\frac{7+8}{16} \times 100 \%=93.75 \%
$$

Dari hasil data pelatihan didapat akurasi mencapai 93.75\%, artinya sistem ini bisa digunakan dalam identifikasi penyakit sel darah. Akurasi sistem identifikasi tersebut cukup tinggi, sehingga sistem akan digunakan sebagai identifikasi data uji yang tidak diikutkan dalam proses pelatihan. Hasil identifikasi data uji dapat dilihat pada tabel 4 .

Tabel 4 Hasil identifikasi data uji

\begin{tabular}{cccc}
\hline Citra & Jumlah & Identifikasi Benar & Akurasi \\
\hline L & 2 & 2 & $100 \%$ \\
A & 2 & 2 & $100 \%$ \\
\hline
\end{tabular}

Persentase akurasi dari data uji dihitung dengan persamaan berikut:

$$
\text { akurasi }=\frac{2+2}{4} \times 100 \%=100 \%
$$

Keterangan:

$\mathrm{L}=$ Citra leukemia

$\mathrm{A}=$ Citra anemia

Akurasi identifikasi data uji mencapai 100\%, sehingga sistem tersebut sangat cocok digunakan dalam identifikasi penyakit sel darah.

Sistem identifikasi penyakit sel darah dilengkapi dengan Grafichal User Interface (GUI) untuk mempermudah dalam pengaplikasiannya. GUI ini terdiri dari beberapa tombol, yaitu tombol Buka digunakan untuk menampilkan citra RGB. Kemudian pada tombol Grayscale citra RGB akan dikonversi menjadi citra beraras keabuan (grayscale). Tombol Ekstraksi Ciri digunakan untuk menampilkan nilai-nilai pada fitur GLCM berupa kontras, korelasi, energi dan homogenitas. Proses terakhir didapatkan hasil identifikasi dengan menekan tombol Identifikasi. Contoh tampilan GUI untuk data input salah satu citra sel darah ditunjukan pada Gambar 7. 


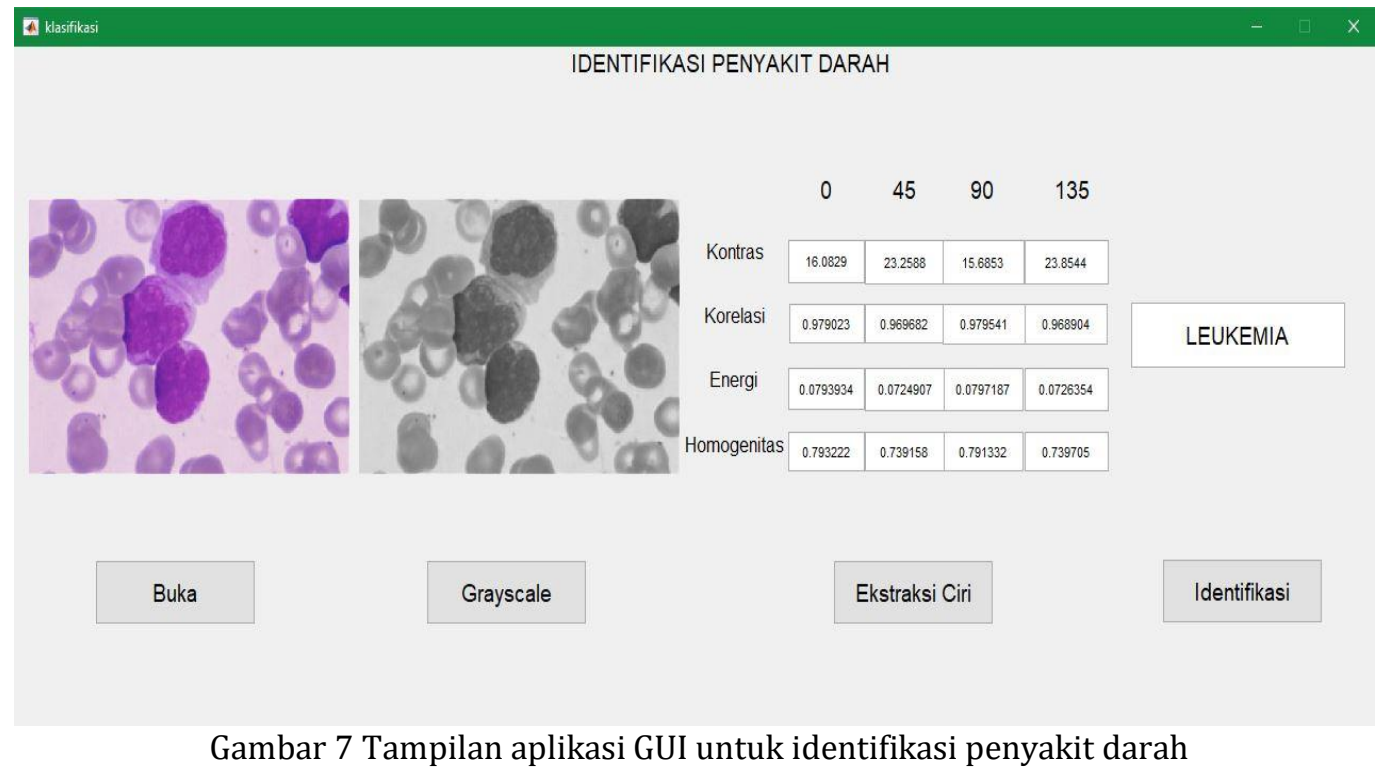

\section{Kesimpulan}

Penelitian ini dilakukan untuk mengidentifikasi citra sel darah menggunakan ekstraksi ciri GLCM. GLCM menghasilkan empat karakteristik, yaitu kontras, korelasi, energi, dan homogenitas dengan 4 arah. Nilai-nilai tersebut digunakan untuk identifikasi penyakit darah menggunakan logika fuzzy mamdani. Identifikasi menunjukkan akurasi sebesar $93.75 \%$ untuk data pelatihan dan $100 \%$ untuk data uji. \

\section{Pengakuan}

Terima kasih kepada bapak Dr. Bintoro S. Nugroho dan bapak Iklas Sanubary, M.Si yang telah membantu dan membimbing dalam penenilitian ini.

\section{Daftar Pustaka}

[1] Susilawati, I., Identifikasi Penyakit Leukemia Akut Pada Citra Darah Mikroskopis. Orbith, 12, 29-34, 2016.

[2] Setiawan, A, E. Suryani, dan Wiharto., Segmentasi Citra Sel Darah Merah Berdasarkan Morfologi Sel untuk Mendeteksi Anemia Defisiensi Besi. ITSMART, 3, 1-8, 2014.

[3] Listia, R, A. dan Harjoko., Klasifikasi Massa pada Citra Mammogram Berdasarkan Gray Level Coocurence Matrix (GLCM). IJCCS, 8, 59-68, 2014.

[4] Syifa, R.A, K. Adi, dan C.E. Widodo., Analisis Tektur Citra Mikroskopis Kanker Paru Menggunakan Metode Gray Level Coocurence Matrix (GLCM) dan Transformasi Wavelet dengan Klasifikasi Naïve Bayes. Youngster Physics Journal, 5, 457-462, 2016.

[5] Mandyarta, E.P, M. Kurniawan, dan R.S. Perdana., Identifikasi Sel Darah Merah
Bertumpuk Menggunakan Pohon Keputusan Fuzzy Berbasis Gini Index. Buana Informatika, 6, 51-62, 2014.

[6] Dewi, D.P.S., Sistem Pakar Diagnosa Penyakit Jantung dan Paru dengan Fuzzy Logic dan Centainty Factor. MERPATI, 2, 361-370, 2014.

[7] Nabella, W. M., J. Sampurno, dan Nurhasanah., Analisis Citra Sinar-X tulang Tangan Menggunakan Metode Thresholding Otsu Untuk Identifikasi Osteoporosis. POSITRON, 3, 12-15, 2013.

[8] Helja, M., Nurhasanah, dan J. Sampurno., Analisis Fraktal Citra Mammogram Berbasis Tekstur Sebagai Pendukung Diagnosis kenker Payudara. POSITRON, 3, 35-38, 2013.

[9] Kipti, M, Y., Deteksi Awal Penyakit Retinopati Hipertensi dengan Pendekatan Analisis Fraktal Citra Fundus Mata, Surakarta: FMIPA Universitas Sebelas Maret, 2015.

[10] Prasetyo, E., Pengolah Citra Digital dan Aplikasinya Menggunakan Matlab, Yogyakarta: ANDI, 2011.

[11] Gadkari, D., Image Quality Analysis Using GLCM. Orlando: University of Central Florida, 2004.

[12] Dillak, R.Y dan M.G. Bintiri., 2013. Klasifikasi Citra Diabetic Retinopathy Menggunakan 3D-GLCM Projection. SNATI, 1:46-51.

[13] Kusumadewi, S. dan H. Purnomo., Aplikasi Logika Fuzzy untuk Pendukung Keputusan. Yogyakarta: Graha Ilmu, 2010. 